\title{
『八丈筆記』における八丈島の食生活に関する一考察
}

\author{
豊山恵子*1 安藤屯ち*2 伊津信之介*3 田所忠弘 $* 4$ 一寸木宗一*5 \\ $\left(* 1\right.$ 近畿福祉大学 $* 2$ 元文教大学女子短期大学部 ${ }^{* 3}$ 東海大学福岡短期大学, \\ *4東京農業大学 $\quad * 5$ 神奈川県立栄養短期大学)
}

\section{A Research on the Dietary Habits in Hachijo island : Daily Meals in Hachijo-Hikki}

\begin{abstract}
Keiko Toyama*1, Machi Andou*2, Sinnosuke Izu*3, Tadahiro Tadokoro*4, Soichi Chokki*5
${ }^{* 1}$ Kinki Welfare University, 1966-5, Takaoka, Fukusaki-chou, kanzaki-gun, Hyogo, 679-2217

*2Bunkyo University Women's Junnior College, 1100, Namegaya, Chigasaki-shi, Kanagawa, 253-0007

${ }^{* 3}$ Tokai University Fukuoka Junnior College, 1137, Taku, Munakata-shi, Fukuoka, 811-4198

${ }^{* 4}$ Tokyo University of Agriculture, 1-1-1, Sakuragaoka, Setagaya-ku, Tokyo, 156-8502

${ }^{*}$ Kanagawa Prefectural Junior College of Nutrition, 2-43-1, Sakuragaoka, Hodogaya-ku Yokohama-shi,
\end{abstract}

Kanagawa, 240-0011

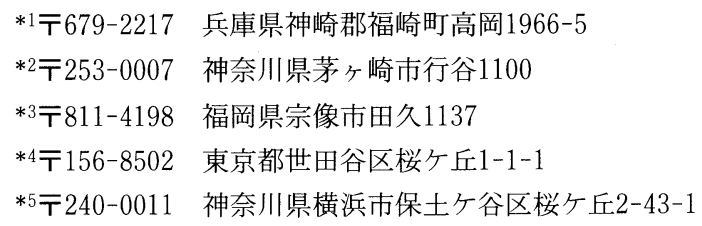

\section{1.はじめに}

江戸時代，幕府の直轄領，天領であった伊豆の国は， 流刑の地でもめった。このため, 一般の渡航は厳しく制 限されていたので，民間人による紀行文はない，島の実 情を伝える見聞録は，幕府関係の記録や報告の類に限ら れている. 当時のことを記録した古文書によると, 食料 不足は日常的でたいへん困穹していた，僅かばかりの米 に, 雑穀, 山野草, 海草や魚介類などで, なんとか飢え を凌いでいたのが実情のようである. 台風や強風, 長雨, 日照り, 冷夏などの異常気象が起きると, 米や雑豰類の 収穫が低下して, たちまち飢饉状態に陥ることが多かっ たという。

しかし, 古くより八丈島の人々は, 健康で長寿であっ たという1) 3)，一見矛盾を感ずるような知見が見られる.

$348(66)$
そこで,このような食環境における一般庶民や流人達が， 平素どのような食事内容であったのか興味を抱かせる点 が多い，今回は，寛政年間の八丈島に自生する植物や食 生活の様子について検討し, 若干の知見を得たので報告 する.

\section{2. 調査方法}

本報告は, 岡山市立図書館蔵『八丈筆記』4)寛政写 本, 文化写本を訳文し, 当時の山野に自生している植物 や食生活の実態について調べたものである.

訳文にあたっては『八丈筆記』の寬政写本を底本とし， 文化写本で校合決定した．使用している漢字は新旧にか かわらず，常用漢字とし仮名を漢字に改めた時は，もと の仮名部分については（ ）を付さずルビとした．変体 仮名は常用平仮名に統一した. また, 読み易いように随 


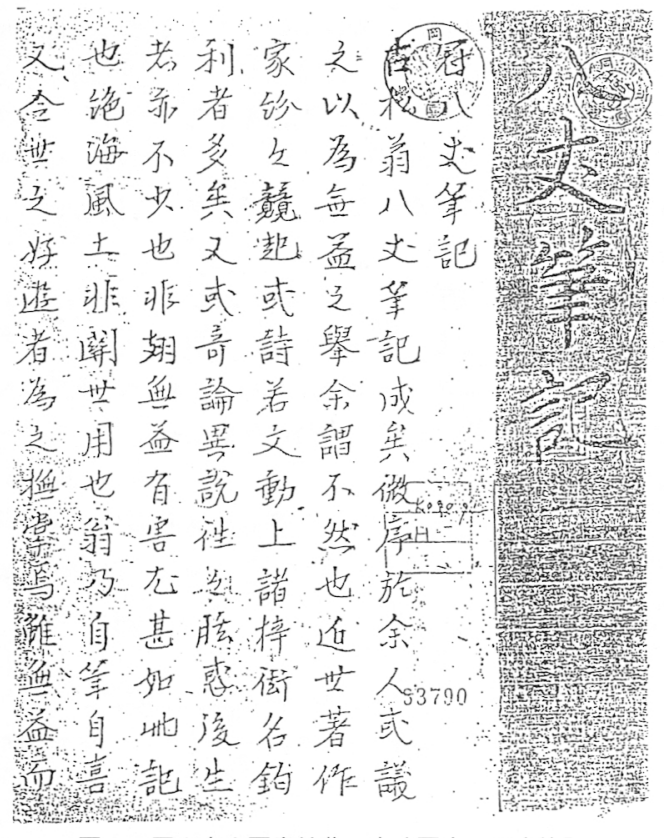

図 1 岡山市立図書館蔵 寛政写本 八丈筆記

時, 句読点を付した.

『八丈筆記』は, 今から約 200 年前, 1796 年（寬政 8 年） 伊豆代官, 三河口太忠が幕命を受け，江戸から伊豆諸島 巡見の旅に出た時の見聞録である. 伊豆七島の八丈島を 中心とした日常生活, 風俗, 習慣などに関する貴重な記 録が記されている，図1に『八丈筆記』の書き出しの文 章を示した。

また，ほぼ同年代の古文書『八丈誌』5), 『八丈紀行』6), 『土佐国群書類従一漂流の部』7よ゙も訳文して, 寛政年 間の食生活に関する手掛かりを得た。

\section{3. 調査結果および考察}

\section{（1）伊豆諸島巡見の旅と『八丈筆記』}

伊豆国代官所は，その管轄地域が広く，離島まで直接 に支配を及ほすのは, 実務上大きな困難があったため, 現地には地役人を配置して, 実際の統治に当たらせると いう仕組みであった。代官はその任期中に一度だけ諸島 を巡見して行政指導に当たるというのが，江戸時代の慣 例であった. 1795年（寛政 7 年）代官江川太郎左衛門の 後任として任命された三河口太忠が, 寛政 8 年 4 月 14 日, 幕命により17名の従者と共に江戸を立ち, 八丈島・八文 小島・三宅島・新島等を見分し, それだれに種々の所務 を果たし, 12月浦賀に帰着し, 翌年正月, 復命した。 そ
の後，寛政 9 年夏，備前国児島郡の海面付州の開拓見分 のため同地に赴き，その余昵に古河古松軒に八丈島等の 見聞を物語り，古松軒がこれを筆録したものである。よ って代官自身の見聞録ということができる．内容は伊豆 諸島の地図を巻頭に載せ，八丈島に関する記事，島への 渡海·島の人口・ 風俗 ·地理 ·生物 · 流人 · 産物 · 言 語·漂着船·気候等について記述されている4).

\section{(2) 寛政年間の自然と人口構成}

八丈島は伊豆七島の一つである，伊豆諸島は，暖流の 黒潮に洗われ，島の周りではカッオ，マグロが獲れ，島 にはソテッ, バナナ等の亜熱帯や熱帯の植物も茂ってい る、『八丈筆記』では当時の様子を次のように記してい る.

「八丈の渡海至って剣難にして, 凡曰本より渡る所, 中華・朝鮮 · 琉球及び壱岐・対馬 ·佐渡 · 松前何れも安 からずといえども，八丈渡海をもって第一とす．豆州下 田浦より己午の間にあたりて百里といえども定かなら ず、先づ三宅島に渡り，この風にてはたやすかるべと いうほどの日和を待ち得ざれば船を出さず。三宅島より 末にあたりて五六十里という。この間に早潮, 黒潮と称 する所有り，早潮は， 巾二丁ばかりにてその流れ瀧のこ とく, 潮のくるかた二段三段ともなりて逆浪立上がりそ の声雷のごとく，聞く人きもを冷やし魂を消す，黒潮は 海面墨をすりしごとく，幾百ともなく渦ばかり流るる故 見る目あやしく、これを見て目くるめかずという人なし． 晴天にて日和よちしけれげ海上穏やかにして右の早潮黒 潮も見えず，これを見るほどの天気なれば決して船を遣 はさざる故に見しという人希なり。もし右の潮に行きあ たれば何国ともなく押し流されて再び州る人なき故，こ れは語りも伝えまた遠く見て, 早潮ならんと察する故也 もっとも順風にて日和もよしという日にも大浪舟を打ち 越す事度々也. 強風からず，よき節は一日のうちに着く. 船心もとなき故随分の順風にあらざれば幾日も日和を待 つ事也.島人七千余人にて三分の一男子にて三分の二は 婦人也. 奇といふべし. 出 $^{4}$

また, 気候は「此島, 暖かなる事, 寒中といへども, 地方の秋季の如し. 夏の間は, 暑気さしてつよからず. 晴日屯れにて, 夕立は度々降る。けふは暑りもなく, 能 日和と見へしも海上より雨雲を催し, 夕立降る事, あや しいと思う程なり。海上より，竜，天上するがごとき度 々なり.」4) と記される.

八丈島は海洋性気候が強いので, 冬は比較的暖かく, また，夏はそれほど暑くない，平均気温が27度を越える ことはなく, 年間気温の差は比較的小さい. 冬は季節風 
が強いので, 体感温度は比較的寒い。しかし, 年間を通 して高温多湿で雨が多く, 快晴日数は年間で僅かに 20 日 前後と少ない様子が記されている. 当時の人口は約 7 千 余人とされ，そのうちの 3 分の 2 が女性であったという.

八丈島における西山上東山の植生はかなり相違してい たようである. 近年においても東山ではタラノキとシイ ノキを主とする原始林的な様相を呈している．集落付近 では, ツバキ, 畑ではオオバヤシカブシャマグサが目立 つ. 西山では, 伐採のため大木が少なくオオバヤシカブ シャマグサやイヌビワが主となり，また，ガクアジサイ が多く山頂付近はタケ，ササの類が群落をなしてい $3^{8) 910)}$. 八丈島には, 水田があり近世中期に存在した. 水田は伊豆諸島では, 八丈島のみに見られるものである. しかし，米の獲れ高は多くなかった ${ }^{9) 10) . ~}$

\section{（3）日常の食生活}

現在の八丈島の食料事情は，本州と変わることなく豊 かである.この食料は，すべて船舶または航空貨物とし て搬送・移入されるものである．故に現在の食料の豊か さは，交通運送手段の発達に支えられている．寛政年間 の八丈島では，食料不足で困窮していた，必要とする限 界のところで, 何とか飢えを凌ぐ事情であり, 従って台 風や強風, あるいは長雨, 日照り, 冷夏などの異常気象 などが起きると，たちまち飢餓状態に陥った．『八丈筆 記』によると，

「作るものには麦, 稗, 粟, 大豆, 蒝麦, 琉球芋など 有りて, 米も少しずつ出来れども, 島人十分の一の食事 もなきことなり,それ故にやこの島にはあした草という， 異草有りて，山々に生うる事おびただしく，刚り取れば 後より，生い茂りて四季に絶えず。島人はこの草を取り て平生の食事とす，中以上の人は，米一合，中以下の人 は麦にても一合を以って一日の扶持とし，不足はこのあ した草を用い，地かたにて大根の葉の飯をするがごとく にして，食とする事なり．小童より馴れたるは飽くとい う事もなく，また功ある草にや，地かたのごとくにやみ 煩う者も希に年もみな七十, 八十に及ぶ霊草と言うべし. 度々，伊豆の地へうつし植えしかども土地にあわざるに や一，二年のうちには，少なくなりてついには枯れうせ るという．地にはまたかかる霊草を生ず，造物者のなす 所，人智をもってはかるべからず.」4) と記される.

また，1746年（延享 3 年）に土佐から, 八丈島に漂着 した船に乗り合わせた者の記録, 『土佐国群書類従-漂流 の部』によると概ね，次のような意味のことが記されて いる.「島中, 粟·芋・あした草の出来るにより沢山に 作る也. 次に大根·無・ひともじ・ごぼう・黄瓜など作
る事，御国に替わる事なし.」7) とされる.

伊豆諸島では古くから食料獲得の方法やその技術が伝 承されている，そのひとつに焼畑がある，八丈島では畑 地をショと呼び，イモショは焼畑をさしておりキリカエ バタともいう. 大間知 ${ }^{10)}$ は著書にイモショについて里芋 を栽培することに重点をおいた証拠であると記述してい る.

今から約 200 年前, 八丈島, 青ケ島でもたんに芋とい えば里芋のことでありヤツガシラ, タゴベー, トーイモ などたくさんの種類の里芋がつくられていた．里芋は粟 とともに基幹作物として, 当時は久かせないものであっ た。

しかし，食料が欠乏しやすい自給体制の孤島に恩恵を 与えたのはカンモ（甘藷）であった。 カンモは唐芋の誂 りで島ではこのように呼んでいた。 カンモが日常食とし て，欠かせないものになったのは，栽培に成功した文化 文政（1804～1829年）の頃といわれる．風害に対する抵 抗力の強いカンモの耕作の普及により里芋に加えて重要 な食料源となった ${ }^{899)}$.

前述の『土佐国群書類従-漂流の部』(1746年) にみら れる芋は島の唐芋史より里芋であろう. 他方, 『八丈筆 記』（1797年）が記載された時代は，カンモが欠くべか らざる重要な食料として, 不抜の根を張り始めた頃で, 文中にみられる琉球芋はカンモと思われる.

このように島の人達の, 日常の食事は麦や栗, 芋（力 ンモ, 里芋), アシタバが大切な食料源であった。岩間 のせせらぎには，水芋の自生地もある．八丈島は温暖多 雨のため, 食用になる野生植物があり, 食に難儀する島 の人々の糧であった. さらに磯辺には海藻類, 巻き貝や 海胆を採って食べる「磯物採り」(10)が行われ，流人達は これに頼る者が多かったという。

伊豆諸島では昭和 20 年代頃まで, クズ, テンナンショ ウ，キカラスウリなどから澱粉採取を行っていた．テン ナンショウは八丈島ではヘンゴとも言われ，これを団子 にして食べる習慣がある．食用だけでなく薬用としても 利用されていた．この常食されたヘンゴ団子は，富岡 ${ }^{9)}$ の報告によると, 精白米とほぼ同程度かそれ以上の栄養 価値があり,ヘンゴを澱粉性食品として利用する技術を, 確実に伝承保存することは将来, 重要な意義をもつとし ている.

\section{（4）流人達の食生活}

八丈島は流罪地であった。『御定書百ケ条』では遠島 について, 江戸より流罪の者は, 大島, 八丈島, 三宅島, 新島, 神津島, 御蔵島, 利島, 右七島の内に遣わすとさ 
れている. 遠島に期限はなく, 恩赦も武士には 30 年以上, その他常人は 5 年以上経たなければ，恩赦の対象にはな らなかった. しかし, 大抵の者が島で数年の間に, 死没 しているようである811).

船が島に着くと流人達は役人に引き渡され, その後, 籤によって島の各村に割り付けられる. あとは各自, 自 力で勝手に島内で生活してゆかなければならなかった. 身よりはなく, 禁足が解けると, その日から食べるにも 困った. 自力で畑を作り, 魚介類や海藻を採り, 小屋を 建てて住まいするなど, 旺盛な生活力を必要とした。仲 間の流人，島民に物乞いするしかない状態であるが，島 民の生活そのものが豊かでなく, 毎日が飢餓と戦う日々 であるといっても過言ではなかった ${ }^{10)}$. 貧しい狭い島で は，流人が増すほどに島は飢餓状態になった。テンナン ショウ (天南星), アザミ(薊), トコロ (野老) など食 ベられそうな野草や，海辺で磯ものを採ったり何でも捜 しては食べていた. そのため, 毒草を食べて悶死する者, 波にさらわれて溺死する者が絶えなかったといわれる.

しかし, 八丈島の温暖な気候は, 流人達の島での生活を 支えていたようである11).

離島と飢えとは，いつの時代にも切り離すことができ ない問題であった. 江戸時代, 幕府は島人の迷惑などお かまいなしに流人を盛んに送り込んだが，ひとたび飢え に見舞われても,さしたる援助の手を差しのべなかった. しかし，『八丈筆記』には食べ物には困窮するが情に厚 く, 住みやすい所であることを次のように述べている.

「金銀銭不通の所なれば，…地方とは風俗の違い大な り、鬼住（む）やうに思はるる僻地といへど却ってよき 事多し、うらやましき土地なりといふべし. 版と記され ている.このように倒れてしまう廃人もあったが, 一度, 島の生活に順応すると, 長寿を全うすることができたの かも知れない.

\section{3.おわりに}

古くより八丈島は, 長寿の島として知られている. 寛 政年間における見聞録『八丈筆記』から，当時の山野に 自生している植物や生活の様子について検討した. その 結果, 一般庶民の日常食の特徵は, 雑穀を主食とし, 野 山に自生しているアシタバやヘンゴ団子を, 常食してい ることであった。

古文書1)3)によると八丈島に長寿者が多いのは, 食生 活内容や精神面, 社会生活面でのストレスの少なさが挙 げられている. 食生活では, 雑穀と魚介類, 野菜の混食 によるところが多い.しかし，セリ科に属するアシタバ
と呼ぶ島のどこにでも自生している植物を食べることの 影響が強いともいわれている.アシタバは葉を摘んだ次 の日には，そこから次の芽が出ているので「明日葉（ア シタバ)」と名づけられた.『八丈筆記』ではアシタバは 霊草とも呼ばれ，四季を通じて食用・薬用とされていた．

アシタバは他の古文書3)でも，「つらつら思ふにアシ タ草は，国にても，余地有所へはうえおきて，年をつみ たらんには，貧をたすけ，又，凶年のよきそなひなるべ し、アシタ草の食となる事, 菜根のたぐひにあらず。五 穀の貧しき時に至りて, 生命の主となるべき物, アシタ 草にまさるはあらじとぞ，おもはる.」と記されている.

アシタバの成分值は表 1 の通りでビタミン $\mathrm{A}, \mathrm{B}_{1}$, $\mathrm{B}_{2}, \mathrm{C}$ 等が豊富である。このアシタバは，八丈島はも ちろんのこと青ケ島や小島では古くから大切な青野菜と して，採取されていた。

八丈島ではこのような自然採取と粗放な畑作が多かっ た. 畑地をショと呼ぶが，このショ抢よびタバラ（水田） に肥料として，人糞尿を用いることを行い始めたのは，

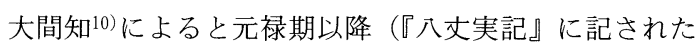
元禄16年，1703年の記事による）であるとされる. 気候 の多雨湿潤性によって，作物は十分に成育していたよう であるが，打ち続く不作で作物の実入りが悪くなり牛糞 その他の下糞を用いるようになったという。しかし，八 丈小島では，用いなかったようである，一方，『土佐国 群書類従-漂流の部』（1746年）では,「惣じて田畑のこ やしに不浄を用いるという事なし.人家に不浄家あれど も桶なし.」とされ，人糞尿は用いていない記録も遺さ れている. 牛糞が元禄期以前に用いられているか否かは 明らかでないが, 近世における牛の駄屋肥は大切な肥料 であった。

常食とされたヘンゴは表 1 に示す通り亜鉛, マグネシ ウム, 銅, 鉄などの微量元素が多く含まれていることが 富岡 ${ }^{9)}$ によって報告されている.

また，流人達の食生活は，温暖な気候と島の人々の温 情で, 難儀しながらも細々と支えられていたようである. 今後, 八丈島の救荒食の調査と併せて検討したいと考え ている.

八丈島では皆, 長生きをして80歳, 90歳の者は, 珍し いものではなく 100 歳にも至らなければ，長生きとはい わなかった，病気は少なく，1万人程度の人のなかに盲 人は一人もなく, 中風, 攋風も希れであったと言う11)12).

江戸時代，三大飢饉のうちでも，特に天保の飢饉は餓 死者が相次いだ，八丈島では仏教思想による肉食禁止の 時代にも, 飢餓の際, 獣肉を食用としていた。「牛喰い」 
表 1. シマテンナンショウ（生），ヘンゴダンゴおよびアシタバの食品成分分析值

（可食部 $100 \mathrm{~g}$ あたり）

\begin{tabular}{|c|c|c|c|}
\hline 栄養素名 & $\begin{array}{l}\text { シマテンナンショウ*1 } \\
\quad(\text { 球茎·生 })\end{array}$ & ヘンゴダンゴ*1 & アシタバ*2 \\
\hline エネルギー（kcal） & 110 & 156 & 33 \\
\hline タンパク質 (g) & 3.2 & 3.0 & 3.3 \\
\hline 脂質（g） & 0.2 & 0.9 & 0.1 \\
\hline $\begin{array}{l}\text { 炭水化物 } \\
\text { 糖質 }(\mathrm{g}) \\
\text { 繊維 }(\mathrm{g})\end{array}$ & $\begin{array}{r}27.1 \\
3.0\end{array}$ & $\begin{array}{r}33.9 \\
0.2\end{array}$ & $\begin{array}{l}5.2 \\
1.5\end{array}$ \\
\hline $\begin{array}{l}\text { 無機質 } \\
\text { カルシウム }(\mathrm{mg}) \\
\text { リン }(\mathrm{mg}) \\
\text { 鉄 }(\mathrm{mg}) \\
\text { ナトリウム }(\mathrm{mg}) \\
\text { カリウム }(\mathrm{mg}) \\
\text { マグネシウム }(\mathrm{mg}) \\
\text { 銅 }(\mathrm{mg}) \\
\text { 亜鉛 }(\mathrm{mg})\end{array}$ & $\begin{array}{c}26.9 \\
34.4 \\
0.34 \\
3.1 \\
281.9 \\
32.6 \\
200 \\
1.2\end{array}$ & $\begin{array}{l}31 \\
35.8 \\
0.78 \\
384 \\
217 \\
24.1 \\
97 \\
1.39\end{array}$ & $\begin{array}{l}65 \\
65 \\
1.0 \\
60 \\
540 \\
26 \\
0.16 \\
0.6\end{array}$ \\
\hline $\begin{array}{l}\text { ビタミン } \\
\mathrm{A} \\
\begin{array}{|l}\text { レチノール }(\mu \mathrm{g}) \\
\text { カロテン }(\mu \mathrm{g}) \\
\text { カチノール当量 }(\mu \mathrm{g}) \\
\mathrm{B}_{1}(\mathrm{mg}) \\
\mathrm{B}_{2}(\mathrm{mg}) \\
\text { ナイアシン }(\mathrm{mg}) \\
\mathrm{C}(\mathrm{mg})\end{array}\end{array}$ & $\begin{array}{l}0 \\
0 \\
0 \\
0.19 \\
0 \\
0.70 \\
9.29\end{array}$ & $\begin{array}{l}0 \\
0 \\
0 \\
0.11 \\
0 \\
0.61 \\
11\end{array}$ & $\begin{array}{c}0 \\
5300 \\
800 \\
0.10 \\
0.24 \\
1.4 \\
41\end{array}$ \\
\hline
\end{tabular}

*1八丈島におけるテンナンショウの食用化に関する伝承技術の調查研究・富岡 ${ }^{9}$ の報告より引用する.

*2科学技術庁資源調査会編「五訂日本食品標準成分表」133

と呼ばれるものである11). 牛喰いは, 殺したり, 乳を飲 むことと共に忌まれたが，飢饉時には半ば公然と行われ た.中世から近世にかけて，飢饉に際して食べたいとい う記録が幾つも見られる810)。その一番古いのは康正 2 年 (1456) であり, 次は約 50 年遅れて永生 2 年のことで ある.『八丈島年代記』，慶長 4 年（1599）の記録に「大 風吹いて耕作悉く失われる. 百姓大勢牛喰いに山へ出 る.」8)といった記述がある.

牛は最も重要な運搬交通の手段であったが，飢饉時の 非常食物としても大切なものであった．この他，日常食 として魚介類, 海藻類, アシカやウミガメなどの海の幸 を食用としており，鳥類を含めてこれらの動物性食品が， 食生活に果たした役割については今後の課題としたいと 考えている.

以上のように長寿を誇ったいにしえの人々から，長生 きが喜べるような生活習慣を学びたいと考え, また少し でも生命の質 (QOL) について検討する一助となれば
と追究を試みたものである。

\section{[謝辞]}

本報告における訳文は, 本邦の古典日記についてご造 詣の深い前神戸女子大学瀬戸短期大学教授 ·水川喜夫先 生に細部に亘り詳細な御指導を戴いた。またヘンゴの食 用化に関する貴重な文献の御提供, 御助言を戴いた聖徳 短期大学教授, 富岡和夫先生に付記して禹心より感謝申 し上げます。

\section{参考文献}

1）樋口秀雄 伊豆海島風土記, p. $20 \sim 22,155,156$, 緑地社, 東京, 1974

2）三島勘左衛門 日本庶民生活資料集成，宮本常一，原口虎 夫編, p. 1，407 438，646, 三一書房，東京， 1968

3）金山正好 伊豆諸島巡見記録集 p.43，133，177，173～ 186, 緑地社, 東京, 1974

4）古河古松軒 八丈筆記, 岡山市図書館蔵, 1797

5）大原正矩 八丈誌，岩瀬文庫蔵，1854 
6）細川宗仙 八丈紀行, 国会図書館蔵, 1851

7）不詳 土佐国群書類従-漂流の部 2 八丈島漂流記, 東京 大学資料編纂所, 1746

8）東京都八丈島八丈町教育委員会 八丈島誌，八丈島誌編篹 委員会, p. 141 215，378～382，451～453，1793

9）富岡和夫（財）日本食生活文化財団 - 日本食生活文化調査 研究報告集 10, p. $47 \sim 66,1994$
10）大間知篤三 八丈島, p. $43 \sim 46,47 \sim 66,76 \sim 90,141 \sim$ 145，186～195, 角川書店, 1948

11）段木一行 海と列島文化，p. 7，156，198，小学館，東京， 1991

12）近藤富造 八丈実記， $6 （ 7) ，$ p. $407 ， 435 \sim 473 ， 468$, 緑地社, 東京, 1976

13）科学技術庁資源調査会編 五訂日本食品標準成分表，2000 